This is a self-archived version of an original article. This version may differ from the original in pagination and typographic details.

Author(s): Husu, Hanna-Mari; Kumpulainen, Kaisu

Title: Promoting neoliberal ideology in Finnish rural community development : the creation of new moral actors

Year: 2019

Version: Accepted version (Final draft)

Copyright: @ 2019 Informa UK Limited, trading as Taylor \& Francis Group

Rights: In Copyright

Rights url: http://rightsstatements.org/page//nC/1.0/?language=en

Please cite the original version:

Husu, H.-M., \& Kumpulainen, K. (2019). Promoting neoliberal ideology in Finnish rural community development : the creation of new moral actors. Local Government Studies, 45(6), 893-912. https://doi.org/10.1080/03003930.2019.1635015 


\title{
Promoting neoliberal ideology in Finnish rural community development: the creation of new moral actors
}

\begin{abstract}
Today's political ambitions are based on the neoliberal aspiration to diminish the state's role and responsibilities, and to transfer those responsibilities to local communities and individuals in ways that idealise those communities, promising to 'give power to the people'. Instead of highlighting individualism, neoliberalism now celebrates communities and participation. This article deals with the effects of this ideology with regard to Finnish rural policy objectives. Drawing on Finnish village action programmes as data, we argue that these ideological views aim to transform individuals and create new moral actors. Our research indicates that Finland's rural policy objectives invoke actors that are responsible for their communities, have an 'enterprising spirit', and are change-friendly and innovative. However, the ideology disregards the economic and social preconditions and resources necessary for building affluent communities and villages, which are difficult to attain when there is less government involvement. Thus, rural communities face increasing demands and less government involvement.
\end{abstract}

Keywords: Neoliberalism, ideology, community development, rural policy objectives

\section{Introduction}


This article focuses on the ideological aspects of community development in the context of Finnish rural policy. We explore Finnish rural community development programmes and the role of local communities in them. We are particularly interested in identifying the ideological characteristics that rural communities and ideal rural citizens should have according to the rural policy objectives that emerged in Finland at the beginning of the 2000s. We ask: what kind of ideal citizen and community can be found in the rural policy objectives? What moral ideas and moral characters can be found? Finnish rural policy involves many activities related to administrative goals, development issues, research and politics. Rural policy objectives generally aim to develop the countryside, rural communities and villages, and they deal with concrete developmental goals and (new) responsibilities, tasks and instructions for rural communities. These policy objectives - as formal aspects of Finnish rural policy - constitute a link between rural policy and local rural communities.

We are further interested in how the ideas of local communities and ideal citizens resonate with neoliberal ideology. Neoliberalism has had enormous impact on various forms of policymaking, but instead of highlighting individualism, it now celebrates communities (e.g. Cowden and Singh 2017; Sage 2012; Driver and Martell 1997). This represents an aspiration to synthesise neoliberal economic and social policy with the ideal of community (Cowden and Singh 2017: 273). Community development approaches have been widely emphasised in European Union (EU) regional and rural policies. Various 'bottom-up' and 'place-based' practices and projects are seen as the most important instrument for developing local communities in rural areas. The discourse of participation has been widely adopted in policy circles to emphasise the role and empowerment of local people in development (Eversole 2010). Rural community development research today often views local communities from the 
perspective of participation (Edwards 1998), a reaction against the 1960s and 1970s view of citizens as passive targets of social services (Richardson 1983, 3).

As a representative of the Nordic welfare state model, Finland has traditionally equalised income, wealth and social background among different groups through redistributive taxation. Nevertheless, since the 1990s Finland has increasingly adopted neoliberal policies in which public services are seen in terms of economic cost, and social justice and equality are less important than the freedom to choose services. After joining the EU in 1995, Finland was increasingly influenced by the EU's rural policy strategies and networks (e.g. Hyyryläinen 2000). The adoption of neoliberal principles was also a reaction to the 1990s recession and the financial difficulties facing the public sector, state and municipalities. In Finland, neoliberal policy has been implemented through ministries and public bodies (in particular, the Ministry of Finance) whose views are supported by experts on business and administration. Hence, the realisation of these neoliberal policies has relied on technical solutions and the use of expert knowledge within the administrative field, rather than on the explicit political rhetoric or values of political parties (Patomäki 2007). In addition, the Ministry of Finance's policies, budgets and key actors have remained relatively consistent, providing a framework to which any government needs to adjust its goals, regardless of which party is in power (e.g. Milios 2004, 208-209).

However, traditional welfare state thinking has also remained consistent in terms of rural community development, as the rural objectives generally highlight equality and the equal rights of all citizens, irrespective of residential location. The interests of various actors, negotiations and compromises collide; rather than neoliberalism imposing itself as the hegemonic ideology, neoliberal interests need to challenge and even adjust themselves to the egalitarianism, solidarity and corporatism of Finnish welfare society. Yet, the rural objectives 
clearly represent certain types of neoliberal desire: the objectives ideologically suggest what kinds of communities there should be in villages, how voluntary work should be organised, and what should be (morally) expected of villagers. We explore these rural objectives as ideological efforts to renegotiate responsibilities and redefine boundaries for different actors (the state, municipalities, civil society, village associations, villagers etc.).

Our article represents critical research in rural community studies. Earlier critical studies have referred to the governing perspective (Johansen and Chandler 2015; Kumpulainen 2016; Marinetto 2003; Rose 2000), arguing that neoliberal community development is not about transferring more power to local people, but rather about withdrawing government resources from communities. An increased responsibility for local affairs does not lead to a position in which citizens suddenly have more power (Herbert-Cheshire and Higgins 2004). There is also a danger that efforts to empower communities will create regional inequality, as some actors are better able to take advantage of community-led approaches (Eversole 2010; Herbert-Cheshire and Higgins 2004). Rural community development research has often focused on participation (Eversole 2010; Edwards 1998) from the point of view of those who are left out of decision-making processes (e.g. Hart 2013), elderly people (Liu and Besser 2003) and immigrants (Cristancho et al. 2008). There has also been research on rural policy strategies (Herbert-Cheshire 2000) and the impact of LEADER projects (e.g. Bosworth et al. 2016; see also Navarro, Woods and Cejudo 2016 on critiques of LEADER projects). Our focus on ideology is also distinct from critical approaches that link community development to a theoretical idea of governance influenced by the Foucauldian analysis of power, in which power exists and is diffused and exercised in governmental rules and various networks, practices, discourses and technologies (e.g. Johansen and Chandler 2015; Kumpulainen 2016). 


\section{Finnish rural policy and the role of community development}

The EU provides a general framework for rural development, challenging the earlier idea that rural policy should be specific to nation-states. The market-liberal EU influences and transforms its member states' 'social and administrative model arrangements', which were previously based on reregulation and deregulation (Veggeland 2017, 100). This creates a certain practical reality for actors on different levels: the national level, including ministries and government decision-making, in turn influences provincial, municipal and local-level decision-making. Thus, the ideological aspirations that appear in rural objectives are not only ideal constructions, but also run alongside neoliberal institutional and administrative transformations and practices that are generated from top to bottom and are linked to new public management, privatisation, the channelling of (project) funding, public procurement and budget-planning (e.g. Saad-Filho and Johnston 2005). Lower-level actors operating in the field need to respond and react to these changes, because they need to abide by EU and European Commission legislation and decisions (e.g. Milios 2004).

The current emphasis on local communities' role in rural development in Finland was a consequence of the adoption of (global) neoliberal norms and politics. For instance, the EU LEADER approach is a tool to develop rural areas without direct state intervention, by financing local community development projects according to rural policy strategies (Falkowski 2013). It is extensively used in Finnish rural community development projects. In LEADER, there is the idea that rural development should always arise from local needs and local actions, whether it concerns livelihoods, social problems, tourism or environmental issues. There has been a lot of research on the impacts of LEADER (e.g. Bosworth et al. 2016), and also critical studies that question these projects' efficiency and bottom-up nature (Navarro, Woods and Cejudo 2016). LEADER's 'programme structures and financial 
constrains have imposed a de facto top-down system that constrains local discretion' (Navarro, Woods and Cejudo 2016, 272). LEADER has also been criticised for creating or exacerbating inequalities between groups within local communities by allocating funds to local elites (e.g. Dargan and Shucksmith 2008; Navarro, Woods and Cejudo 2016).

The LEADER initiative aspires to decentralise power and transfer it to local communities, but at the same time it also aims to transfer responsibility to the local level (Cheshire 2006). In Finland, participation and bottom-up approaches have been popular in the 2010s, particularly in regional and rural policy programmes. LEADER and different methods of citizen participation have also been increasingly adopted in urban areas with regard to participative budgeting.

\section{The background of the Village Action Association of Finland}

The Village Action Association of Finland is a feature of Finnish rural policy. It was established in 1997 as a part of the process to integrate the village action movement into Finnish rural policy, and it reflected a more strategic approach to rural community development (Kumpulainen 2016). At that time, central actors influenced both the Finnish Village Action Association and other Finnish rural policy networks. For instance, at the beginning of the 2000s the same person was Chair of the Village Action Association of Finland and Chief Secretary of the Rural Policy Committee (which falls under the Finnish government) (see Ministry of Agriculture and Forestry of Finland 2019).

The Finnish village action movement was established in the 1970s in reaction to the depopulation of rural areas. At first, the village action movement resembled a protest movement, but in the 1990s it became integrated into national rural policy networks. The new 
politics changed the role of the village action movement, which started to respond to EU guidelines, leading to the adoption of new practices such as publishing rural policy objectives (Kumpulainen 2016). Finland can be understood within the Nordic model, which is characterised by a close relationship between the state and civil society (Trägårdh 2007), and which is also related to consensus-seeking and a weak notion of opposition (Stenius 2010, $31)$.

Finnish rural politics and national rural policy objectives guide villages to adopt new practices and values. The rural policy objectives construct new realities for the villages and justify local communities' new responsibilities, even as the idea of the welfare state is being reformulated. This attempt to define villages' role through village associations is not only an effort to seek technical solutions, but also involves two main ideological and political goals: 1) to save the Finnish countryside and its villages; 2) to increase the responsibilities of civil society and promote the idea of active citizenship. In addition, these programmes orient the funding of rural research and development, and they lobby the government and other political actors regarding the importance of state funding for their cause. Therefore, it is important to draw attention here to a paradox. The Village Action Association does not necessarily embrace neoliberalism or its many consequences for rural areas, such as centralisation and the logic of private profit. However, it may be that it frames its language to be consistent with neoliberal ideology in order to attract a positive response from the government, which in turn leads to the promotion of a neoliberal agenda.

There have been four national village action programmes since the 2000 s, which all indicate the increasing expectations, demands and responsibilities placed on local communities. The most important local actors are village associations, which take rural policy objectives into account in their practices. In Finland, there are 3,074 village associations and 4,235 villages 
('Empowering Villages', 46). Village associations are responsible for many types of activity, such as maintaining and renovating community halls, organising events, and representing the village's interests with regard to city officials (with no support from the state).

\section{Community development in rural policy as ideology}

Community development generally has two meanings. On the one hand, it is a normative social theory related to ideas of empowerment, social justice, solidarity and participatory democracy (e.g. Bhattacharyya 2004; Ledwith 2011. On the other hand, community development is related to politics and the implementation of various forms of (government) policy that aim to develop, empower and improve local communities in order to make them more thriving and affluent in their everyday lives (see Shaw 2004). Community development concerns practices, actions and projects that take place within local communities, that is, in villages, neighbourhoods and residential areas. It is defined as 'a social learning process [...] which serves to empower individuals and social groups by involving them as citizens in collective activities aimed at socio-economic regeneration, development and change' (McCleneghan 2000, 566). It is understood as a means to promote people's well-being, and as a solution for certain social problems such as social exclusion, marginalisation or loneliness (Pawar 2014).

The importance of communities is acknowledged in communitarianism (e.g. Etzioni 1995) derived from Tönnies' formulation of Gemeinschaft (i.e. community) - which emphasises the welfare of communities in terms of the membership, belonging and participation (in networks of family and other social relationships) that are central to human flourishing (Daly 1994, xiii-xiv). This is related to the idea of community development: the strengthening of communities is important because individuals live more fulfilling lives as members of 
communities (Daly 1994, xiv). This implies that individuals are 'social beings born into group identities' who desire community, from which it follows that 'desirable goods will flow from strong communities' (Sage 2012, 367). The concept of 'neoliberal communitarianism' (van Houdt, Suvarierol and Schinkel 2011; Cowden and Singh 2017, 270) - as implemented in social policy - combines the individualistic features of liberalism with an aspiration to make communities more ideal from top to bottom. This is consistent with ideas of community which set it against society or the state, even though communities are also seen as an alternative to individualism (Delanty 2003).

Ideas about communities involve political and ideological interests that are related to normative descriptions of communities and citizens, i.e. what and how they should be. Van Houdt, Suvarierol and Schinkel $(2011,408)$ understand the idealisation of communities in social policies as 'a strategy to manage citizenship', indicating an (active) citizenship that is earned rather than given. This is linked to demonstrations of loyalty to community values, highlighting 'contributions that [citizens] are expected to make to society' (Cowden and Singh 2017, 276; van Houdt, Suvarierol and Schinkel 2011, 416). In a time of austerity and the dismantling of the welfare state, communities represent something that has been lost as well as something that is looked for; they are seen as something that can either solve social problems or enable democratic ambitions (Delanty 2013).

Many have noted the role of community development as an ideological tool. This is related to the 'new tyranny of participation', which hinders the idea of social justice and the redistribution of resources (Ledwith 2011, 29; Berner and Phillips 2005; Cooke and Kothari 2001). Such commentators criticise views of community that challenge the structural understanding of social inequality by emphasising communities' and individuals' responsibilities. They also criticise the means through which state responsibilities are 
transferred to civil society, communities and individuals. The core idea is that individuals, groups and local communities should take more responsibility, but this is problematic: certain groups (which are active in society in general) have more advantages and power than others, while individuals and groups who have a tendency to participate less, and who are not active or demanding enough, are easily ignored (Richardson 1983, 54-67).

We are interested in understanding community development as an ideology. Since the 1990s, the governance paradigm has been a key approach for understanding politics and power, including with regard to community development (e.g. Johansen and Chandler 2015). The governance paradigm highlights power in terms of non-centralised, non-hierarchical networks which involve multiple actors and include 'a wide range of public, private and third sector organisations' that 'participate in governing arrangements through a web of partnerships, voluntary initiatives, tendered programmes and contractual arrangements' (Navarro, Woods and Cejudo 2016, 272). The governance approach rejects the idea that power is centralised, and that it does not pay sufficient attention to the role of interest groups and political conflicts; it also hinders the understanding of structured inequality, and fails to perceive the asymmetrical power relationships between upper, middle and local government, where local levels have significantly less power (Walters 2004; Kjær 2011, 107). For instance, the rural objectives discussed in this paper treat localism as a bottom-up approach where change is understood to derive from the local level, even though the main principles directly resemble public policies formulated by the Organisation for Economic Cooperation and Development (OECD), World Bank and EU at the top level (e.g. European Commission [2014]).

The notion of ideology - rather than governance - draws attention to the interests of actors, political conflicts and power relations. The concept of political ideology refers to 'a set of 
ideas, beliefs, opinions' that imply 'recurring patterns', 'are held by significant groups', ‘compete over providing and controlling plans for public policy' and deal with 'justifying, contesting or changing the social and political arrangements and processes of a political community' (Freeden 2003, 32). This definition is consistent with ideas of power that stress the elite's or powerful actors' decision-making power based on control over resources and the symbolic capacity to produce discourses and propose certain types of relationship (e.g. Gramsci 1971; Woods 1997, 456-457; Shucksmiths 2012). A certain ideology - one that is most favourable to the dominant actors' interests - can be imposed, as dominant actors are able to generate effects (construct discourses, direct practices) on the field in question.

However, ideologies are not transparent and easily recognised as such. For instance, Gramsci’s (1971) idea of hegemony pays attention to how dominant groups aim to build a coherent and legitimate worldview through cultural and moral persuasion (Ransome 1992: $128,135)$. The worldview is constructed to give credit for practices and values that are meaningful to dominated actors (Jones 2006: 46). For Gramsci, the sphere of civil society is central in this sense, because it "blurs the distinction between political authority and everyday life" (Jones 2006: 48). Dominated actors gain possibilities for participation and decisionmaking, which is linked to self-governing individuals (Jones 2006: 60, 61). Laclau and Mouffe (2001: xvii, 137) continue Gramsci's work suggesting politics is not only interest articulation, but struggles over identities, and aspirations to shape political subjects that "are constituted and reconstituted within debates in public spheres", which can also be understood "as a practice of creation, reproduction and transformation of social relations." In this sense, the desire related to community development draws attention to powerful actors' persuasion techniques and aspiration to create consensus by constructing meanings that are appealing and valued by the dominated actors. 


\section{Data and method}

The data we analyse are the village action programmes that emerged in Finland at the beginning of the 2000s. These village action programmes and their objectives reflect rural policies that promote practices and values understood as central to the well-being of villages. The programmes were produced by the Village Action Association of Finland. They deal with economic possibilities and livelihoods, the formation of networks and social capital, project planning, the use of land and energy production, civil action, and the role of culture in rural areas.

Altogether there are four national rural programmes that we use as data:

1) 'The Guidelines of Village Activity', 2000-2002 ('kylätoiminnan suuntaviivat'). The first programme that we analyse is a relatively narrow introduction to village activities, and its goals and purposes mostly use an encouraging tone that does not put demands on villagers, but situates responsibility for development goals at the state or provincial level.

2) 'Village Power!', 2003-2007 ('voimaa kuin pienessä kylässä’). In this programme, the responsibilities of local actors are clearly emphasised. For instance, the second objective, 'Village Power!', includes 53 proposals for action, of which 25 are dependent on the active efforts of village associations.

3) 'The Local Community in Response', 2008-2013 ('vastuuta kantava paikallisyhteisö').

The third programme encompasses not only villages, but also towns and population centres. In this programme local communities are seen as necessary to guarantee the functioning of the welfare state. 
4) 'Empowering Villages: Strengthening Local Communities', 2014-2020 ('voimistuvat kylät: vahvistuvat lähiyhteisöt'). The fourth programme continues the work of its predecessors, and it is typical of these later objectives that they give new responsibilities to village associations, such as for health and safety or water pollution control. The commonest features in these rural policy objectives relate to the provision of services.

Our research questions are as follows. What kind of ideal citizen can be found in the rural policy objectives? What moral ideas and moral characters can be found in these objectives, i.e. what type of moral agency is constructed? We are interested in how community development becomes dependent on individuals in terms of what is expected of them. We study objectives that explore interests related to community development, i.e. the specific set of ideas, beliefs, views and opinions related to community development, its goals and the means to realise those goals.

Our method draws on theoretically based qualitative content analysis (Schreier 2014), through which we aim to identify, analyse and describe the meanings in the data. These four programmes entailed normative stances and tones that were consistent with neoliberal ideology, and we hand-coded the data in terms of the individualistic ideals that neoliberalism highlights. We were motivated by our analytical interest in specific areas and aspects of data, which we coded with regard to our research questions. We were mostly interested in aspects of the data related to descriptions of the normative roles of actors and their relationship to their community in the rural objectives, i.e. what these objectives seek and demand from individual actors in terms of the well-being of the community.

We then formed meaningful units of themes that were related to our research questions, and we grouped together the categories that dealt with the same issue. We were interested in 
identifying the underlying ideas and assumptions (i.e. ideologies) in the extracts. Thus our analysis represents a 'wide content analysis', which 'seeks information outside the text (about the author, the generative situations, from theories)' (Flick 2014, 434).

We found three common categories throughout the data. The first highlights the moral character of responsible and dutiful individuals. The second refers to enterprising and risktaking characteristics. In a similar manner, the third theme builds an idea of individuals living in the community who are change-friendly and enthusiastic, and who perceive challenges rather than problems.

\section{Results}

\section{Individual responsibility: cherish your village}

We found in the data that Finnish rural policy objectives place heavy emphasis on increasing individuals' responsibility for their communities. The objectives define new areas of responsibility for the village associations, and it is expected that the villages will adopt the ideological aspects of the objectives. It is also characteristic of the objectives that they increase their demands and impose their goals upon village associations and villagers. There is little room for alternative realities.

The objectives imply that if village associations do not adopt the models imposed by the objectives, they are likely to perish, as the models are necessary not only for the well-being of their communities but also for society at large (because the state is no longer able to take regional responsibility) (see 'The Local Community in Response', 9): 
Village associations must be able to take responsibility. [...] In these circumstances, it must be considered how the village can organise itself in order to take responsibility. It is possible that the village association will take responsibility both for the expanding types of different tasks related to the village itself and for the special tasks of sector associations. The future lies with associations that take local responsibility. ('The Local Community in Response', 8)

For years people have worked together in villages for the common good. In Finland, as the state developed, the villages were left out of the administrative sphere, as public authority was centralised in the state and municipalities. (Village Power!', 15)

The survival of the village, and the services needed by the villagers, become the villagers' own responsibility.

The objectives also draw attention to the local, and to individuals' loyalties to their homes and localities. Strong local communities are understood as a response to global challenges. Local communities are 'safe havens', as individuals need to escape from uncontrolled global forces. The emphasis on local communities can also be seen as a reaction against rapid technological, economic and societal change (Bauman 2000). Once again, this is related to an ideological strategy in the objectives, which idealise communities in order to promote positive identities, care and love for one's community. The local is defined as a moral concept, and entails 'having responsibility over the place where one lives' (Village Power!').

The idea is simple, but in its diversity and many-sidedness extremely wide-ranging. Do a small act on behalf of your community, for instance two hours of work or a seasonal job. The proposal is suitable for both the countryside and cities, even though 
practices differ. Its realisation requires recognising the issue and organising a little time. ('Empowering Villages’, 38).

The positive meanings attached to identities and communities highlight the goal of the objectives: to increase the civic duties of villagers. Wider social and global problems are constructed as local challenges (not structural problems) that can be solved locally (e.g. 'Empowering Villages', 11). The problems caused by globalisation are presented as uncontrollable and inevitable, and dealing with them requires a local response in terms of risk management and private entrepreneurship. In other words, they can be solved by individualised means. Individuals' personal transformation and changes in moral character are implicitly desired as the solution to the problems of an inefficient welfare state and social defects.

The use of overtly positive aspects of community development to promote an ideological agenda includes a level of concealment in its effort to leave out certain important factors related to funding, structural inequality and the use of time. It is important to pay attention to factors that are not explicit in the rural objectives. 'Empowering local communities' and 'giving power to the people', which are popular rhetoric, are generally positive aspects of community development, but they can also be framed, manipulated, and used to serve certain underlying interests and motives. Potential conflicts or disagreements are concealed. These rural objectives strongly entail a tone of political neutrality, as the political commitments are intentionally left vague and presented as neither right-wing nor left-wing. However, the objectives are consistent with neoliberal ideology, as they resonate with the reduction of government responsibilities, social services cuts, and the reduction of public spending by activating citizens and communities. It can be asked whether the activation of citizens and voluntary-sector organisations to play more responsible roles functions all that well, thanks to 
the scarcity of resources and the lack of coherent central support. In Finland, there is an increasing contrast between affluent cities and the countryside, as well as increasing regional

inequality between the western/southern and eastern/northern parts of Finland (e.g. Leppänen 2011).

\section{Celebrating active entrepreneurship as a moral idea}

Peasant society has traditionally been built on values that stress the importance of hard work, independence and diligence. The rural objectives recognised this at first (e.g. 'The Guidelines of Village Activity'), but the later objectives increasingly shifted emphasis to an idealisation of private enterprise. The ethos of entrepreneurship and the 'self as enterprise' is a central feature of neoliberal ideology (Dean 1995, 559-583). It aims to create a new type of citizen that adopts an enterprising spirit.

The rural objectives demand a more strategic and enterprising attitude from the village associations in order for the latter to develop and take responsibility for their communities. In other words, village associations are encouraged to function as enterprise-like units which practise economic activities and hence achieve the goals of rural policy. Entrepreneurship is also understood to guarantee equality of opportunity ('Village Power!', 47). Thus the principle of equality does not concern equality between regions, individuals or groups, but rather the equality of opportunity that creates possibilities for free enterprise.

The idealisation of entrepreneurship is closely linked to increasing responsibilities, but these are presented as new innovations and opportunities, as aspirations to create a 'buzz'. For instance, the latest rural objective asks why a village's development company could not buy a school and give the municipality responsibility for teaching only, or why a municipality 
could not use village-owned cooperatives to do temporary work or provide nursing services ('Empowering Villages', 40). The objectives point out the challenges that municipalities encounter, and suggest private enterprise as a solution: 'when the budgets of municipalities lose billions of euros, the municipalities are keen to consider new methods of service provision that actors in the villages provide through their businesses' ('Empowering Villages', 40). The objectives gloss over the fact that economic profit-making can be relatively difficult in rural areas. Hence voluntary work within communities becomes idealised as a central strategy.

The role of village associations has expanded in the rural objectives to encompass the provision and development of local services. The idea is that communities willingly take responsibility for service provision and do not expect help from others (the state, the municipality), since making demands and articulating their rights (as citizens) could be interpreted as passivity: 'in order to put these needs into practice, villagers can use more effective means than just waiting for some external actor - the municipality or the state - to come to solve their problems' ('Village Power!', 26).

Passivity is considered negatively, as it conflicts with the norms of entrepreneurship and the 'self as enterprise' project. Avoiding passivity, and creating and maintaining an enterprising attitude towards social circumstances, reflects the moral inclinations of the rural objectives, according to which no help will be granted if the individuals and communities do not help themselves first (through enterprising activities). This starts to resemble the idea of the 'deserving' and 'undeserving' poor, and indicates a significant transformation of the universalist ideals of the welfare state. The focus is on individual behaviour. 


\section{Innovation, positivity and change-friendliness as virtues}

Instead of stressing problematic aspects and structural changes in rural areas, the rural objectives aspire to build the countryside and villages as places of 'creativity' and 'innovation'. There is an effort to develop rural areas as an arena where things are produced (even though the products themselves have changed). Besides local foodstuffs, rural areas should produce culture, well-being, energy and services ('The Local Community in Response'). The countryside and villages can themselves be products for consumption and tourism (e.g. Urry 1995), and this is strongly encouraged in the rural objectives ('The Local Community in Response', 47). The village associations' interactions with the social world are characterised by projects and initiatives in which they are (or should be) constantly applying for funding for development ideas and opportunities, which are presented in positive terms (e.g. 'Empowering Villages', 43).

In order to respond to the (neoliberal) goals and ideas of the rural objectives, villagers would need to go through extensive personal transformations, as the dominant rationale aims to extend the logic of the economy to all activities. Neighbours have always provided help for each other, but the neoliberal economic logic transforms that mutual help into specific products and development projects. Aspects of everyday life such as subjective experience and spontaneity are reconstructed in terms of strategic planning, calculation and projects: 'if there was gross village income and all the unpaid work was included, it could be perceived that, in many villages, the value of unpaid work would be higher than all the money that went through the village' ('The Guidelines of Village Activity', 15).

This reveals that many aspects and areas of life are valued in euros that can be counted and calculated (Rose 1999. The villagers need to change their ways of seeing, understanding and 
feeling, as well as the traditional values around which peasant identity has been constructed. Neoliberal economics and rural objectives aim to implement top-down practices to which people living in rural areas need to respond on a practical level. The desire for new ways of thinking, seeing and feeling can also be seen in the ways culture and well-being are characterised in the rural objectives. Culture is no longer merely a matter of societal, economic and communal resources, but something that can be used to promote well-being:

Strong local culture increases local livelihoods, comfort and quality of life of citizens. The significance of culture in terms of well-being is realised through participation and self-fulfilment. Culture strengthens the social capital of communities, that is, the capacity to work together towards common goals. Being a producer of a distinctive culture will positively influence health and prevent social exclusion. Culture supports coping in daily life. ('The Local Community in Response', 46-47)

There is a heavy emphasis on wellness and well-being. Culture is related to economic and social capital within villages that can be used to achieve goals and activities. Most of all, the role of culture is to serve as an instrument for the objectives' development goals.

In addition, the implementation of rational economic logic is apparent in the parts of the objectives that see agricultural landscapes as something that can be taken advantage of: 'the landscape according to the OECD is a so-called public commodity for which there is much call, but for which market supply is lacking. In agricultural landscape supply, new contractual arrangements as well as guidance for housing and construction are needed' ('The Local Community in Response', 46-47). 
Landscapes, as well as culture in general (including subjective personal experiences), are brought under the logic of economic profit-making and innovation. Although wellness, wellbeing and culture are constructed as important in the rural objectives, the main argument rests on their economic efficacy. This demands the adoption of new types of internalised cognitive thinking, translating traditional forms of social exchange into the logic of economic exchange.

\section{Discussion}

We have found that Finnish rural policy objectives entail political goals that are also doctrines of neoliberal ideology, such as free markets, privatisation, and the reduction of public spending. These objectives idealise communities as a response to global problems, and they emphasise community as a means to the good life and individual well-being. However, the objectives implicitly assume that a sense of community, belonging, identities and influential networks can be created with a top-down approach. Questions of resources and inequality are not explicit in the rural objectives. Cuts to social services are likely to have negative effects on rural areas, where people tend to be older. Such rural people do not necessarily have the skills and knowledge to apply for EU funding or manage different types of project, and they may not be interested in developing their citizenship skills or investing in the idea of 'the self as enterprise'. They do not necessarily have any interest in branding their agricultural landscape according to a rational economic logic.

The objectives state that certain things are important, without paying attention to the economic and social preconditions that are necessary for affluent communities and villages. Rural areas are not attractive in terms of making private profits from public goods (unlike privatised healthcare, for instance). This means that rural actors encounter problems as the 
state withdraws and the opportunities for private profit are scarce. Certain rural areas are better able to benefit from tourism or their location near larger urban areas (see the Rural Policy Committee 2014: 2-3). As a response to the diversity and heterogeneity of Finnish rural areas, rural policy increasingly aims to adopt "a place-based policy, which recognizes the diversity of places and takes into account the starting points and needs of places" (see the Rural Policy Committee 2014: 6). For instance, less than $6 \%$ of the population lives in sparsely populated rural areas, which accounts for $68 \%$ of Finland's surface (Lukkari 2017). These areas are, however, rich in bioeconomy raw materials and provide possibilities for the growing use of renewable energy production and local food production (Lukkari 2017; Rural Policy Committee 2014). Developments in telecommunication and communications have blurred the boundaries between urban and rural areas (Rural Policy Committee) 2014. There are some economic possibilities for future prospect, in particular, if the state and Finnish energy policy start to invest in small-scale production of renewable energy, for example.

The rural objectives assume that the village associations represent all villagers and their interests. The objectives do not pay attention to conflicts or different views concerning the role and organisation of the village. Instead, the objectives embody ideas of neutrality and objectivity. For instance, 'village activities as an unbiased movement effectively gather local residents and resources together, which is necessary to bring about results' ('Empowering Villages', 11). This objective goes on to say that the motivation lies with the community and the work the community needs, and therefore that village activities have a solid basis. The idea of neutrality, and the consensus-seeking nature of the objectives, hides the political and ideological motives behind these formulations (which is typical of Finnish politics in general). 
The government and state are seen as inferior and out-of-date models that cannot provide well-being at a local level; it is a better option for the civil sector to take responsibility for well-being. The state and municipalities are constructed as 'others', 'outsiders' who do not naturally belong to village life. In order to succeed, neoliberal ideology wishes to transform individuals in rural communities. According to this view, individuals should be more responsible for their local communities. Social problems could be fixed by a personal and moral transformation in which individuals and groups did something for themselves and took responsibility.

While we acknowledge that local democracy and activation can be perceived through many less critical lenses - such as localism (e.g. Beukema and Carillo 2004), communitarianism (Etzione 1995) or asset-based community development (Mathie et al. 2017), which would have highlighted different aspects - we suggest that neoliberal ideology seeks to diminish the role and responsibilities of the state (and public-sector spending) and to transfer those responsibilities to local communities and individuals, idealising those local communities in the process.

We understand that neoliberal community development ideology contains an individualised (rather than structural) explanation of social problems, and hence seeks personal and moral transformation as a solution. Hence, the objectives constitute a change in how equality and inequality are understood: equality of conditions has been replaced with a discourse of equality of opportunity related to the dismantling of the state's role in reducing material inequalities between groups and areas, and to the replacement of the state with active rural citizens. Neoliberal community development ideology is a creation that is based above all on human resources, often on the voluntary work of individuals and communities. It assumes that communities will reorganise themselves, and will cognitively and affectively perceive 
the social world and themselves in new and innovative ways. Yet, to a great extent, this is left unsaid in the rural objectives.

\section{Conclusion}

We found that Finnish rural policy objectives involve the idealisation of communities. This is consistent with the idea that neoliberal ideology focuses on communities, community development, and participation. It represents social policy, which highlights social responsibility and obligation rather than economic individualism (Sage 2012: 368). Neoliberal ideology takes advantage to existing cultures such as the village action movement and values such as responsibility that are highly appreciated in rural communities. Local communities and civil action are used as an instrument to make villagers act more responsibly and independently. In the rural objectives, there is a heavy emphasis on building local democracy and activating citizenship.

In particular, we were interested in the kind of moral agency invoked with regard to local communities in rural policy, and we explored who and what the ideal citizen is in rural areas of Finland. Rural policy objectives invoke moral actors that are increasingly responsible for their communities. One of the strategies is to draw attention to individuals' loyalties to their homes and localities. Secondly, we suggest that according to these objectives, individuals should have an 'enterprising spirit' as a moral virtue related to 'the self as enterprise'. The rural objectives demand a more strategic and enterprising attitude from the village associations, as the latter are encouraged to function as enterprise-like units in order to accomplish the goals of rural policy. Thirdly, these rural objectives aim to promote changepositive and innovative moral actors who see opportunities rather than threats and show an interest in activities such as branding their agricultural landscapes as business products. 


\section{References}

Bauman, S. 2000. Liquid Modernity. Cambridge: Polity Press.

Berner, E., and B. Phillips. 2005. 'Left to Their Own Devices? Community Self-Help

Between Alternative Development and Neo-Liberalism'. Community Development Journal 35 (1): 17-29.

Beukema, L., and Carillo, H.J. eds. 2004. Globalism/Localism at Work, Volume 13 (Research in the Sociology of Work). Bingley: Emerald Gould Publishing Ltd.

Bhattacharyya, J. 2004. 'Theorizing Community Development'. Journal of Community Development Society 34 (2): 5-34.

Bosworth, G., I. Annibal, T. Carroll, L. Price, J. Sellick and J. Shepherd. 2016. 'Empowering Local Action Through Neo-Endogenous Development: The Case of LEADER in England'. Sociologia Ruralis 56 (3): 427-449.

Cheshire, L. 2006. Governing Rural Development: Discourses and Practices of Self-Help in Australian Rural Policy. Aldershot: Ashgate.

Cooke, B., and U. Kothari, eds. 2001. Participation: The New Tyranny. London: Zed Books.

Cowden, S., and G. Singh. 2017. 'Community Cohesion, Communitarianism and Neoliberalism'. Critical Social Policy 37 (2): 268-286. 
Cristancho, S., D. M. Garces, K. E. Peters and B.C. Mueller. 2008. 'Listening to Rural Hispanic Immigrants in the Midwest: A Community-Based Participatory Assessment of Major Barriers to Health Care Access and Use'. Qualitative Health Research 18 (5): 633646.

Daly, M. 1994. 'Introduction'. In Communitarianism: A New Public Ethics, edited by M. Daly, xiii-xxvi. Belmont: International Thompson Publishing.

Dargan, L., and M. Shucksmith. 2008. 'LEADER and Innovation'. Sociologica Ruralis 48 (3): 274-291.

Dean, M. 1995. 'Governing the Unemployed Self in an Active Society'. Economy and Society 24 (4): 559-583.

Delanty, G. 2003. Community. London: Routledge.

Driver, S., and L. Martell. 1997. 'New Labour's Communitarianism'. Critical Social Policy 52 (17): $27-46$.

Edwards, B. 1998. 'Charting the Discourse of Community Action: Perspectives from Practice in Rural Wales'. Journal of Rural Studies 14 (1): 63-77.

Etzioni, A., ed. 1995. New Communitarian Thinking: Persons, Virtues, Institutions, and Communities. Charlottesville: University Press of Virginia. 
European Commission. 2014. 'Factsheet on 2014-2020 Rural Development for Mainland Finland'. Accessed 15 November 2018.

https://ec.europa.eu/agriculture/sites/agriculture/files/rural-development-2014-2020/countryfiles/fi/factsheet-mainland_en.pdf

Eversole, R. 2010. 'Remaking Participation: Challenges for Community Development Practice'. Community Development Journal 47 (1): 29-41.

Falkowski, J. 2013. 'Political Accountability and Governance in Rural Areas: Some Evidence from the Pilot Programme LEADER in Poland'. Journal of Rural Studies 32: 70-79.

Flick, U. 2014. An Introduction to Qualitative Research. $5^{\text {th }}$ edition. London: Sage.

Freeden, M. 2003. Ideology: A Very Short Introduction. Oxford: Oxford University Press.

Gramsci, A. 1971. Selections from the Prison Notebooks. London: International Publishers: New York.

Hart, R. A. 2013. Children's Participation: The Theory and Practice of Involving Young Citizens in Community Development and Environmental Care. London: Earthscan.

Herbert-Cheshire, L. 2000. 'Contemporary Strategies for Rural Community Development in Australia: A Governmentality Perspective'. Journal of Rural Studies 16: 203-215. 
Herbert-Cheshire, L., and V. Higgins. 2004. 'From Risky to Responsible: Expert Knowledge and the Governing of Community-Led Rural Development'. Journal of Rural Studies 20: 289-302.

Hyyryläinen, T. 2000. 'Kylätoiminnan perinne sosiaalisena pääomana'. In Eurooppalaistuva maaseutupolitiikka: Paikalliset toimintaryhmät maaseudun kehittäjinä, edited by T.

Hyyryläinen and R. Pertti, 109-119. Tampere: Vastapaino.

Johansen, P. H., and T. L. Chandler. 2015. 'Mechanisms of Power in Participatory Rural Planning'. Journal of Rural Studies 40: 12-20.

Jones, S. 2006. Antonio Gramsci. London, New York: Routledge.

Kjær, A. M. 2011. 'Rhode's Contribution to Governance Theory: Praise, Criticism and the Future Governance Debate'. Public Administration 89 (1): 101-113.

Kumpulainen, K. 2016. 'The Discursive Construction of an Active Rural Community'. Community Development Journal 52 (4): 611-627.

Laclau, E. and C. Mouffe. Hegemony and Socialist Strategy: Towards a Radical Democratic Politics. London: Verso.

Ledwith, M. 2011. Community Development: A Critical Approach. 2nd ed. Bristol: Policy Press. 
Leppänen, L. 2011. Changing Statehood: The Spatial Transformation of the Finnish State. $\mathrm{PhD}$ thesis, University of Turku.

Liu, A. Q., and T. Besser. 2003. 'Social Capital and Participation in Community Improvement Activities by Elderly Residents in Small Towns and Rural Communities'. Rural Sociology 68 (3): 343-365.

Lukkari, T (ed). 2017. Sparsely populated rural areas - full of possibilities. Strategy for sparsely populated rural areas 2017-2020. Publications of the Ministry of Agriculture and Forestry.

Marineto, M. 2003. 'Who Wants to Be an Active Citizen? The Politics and Practice of Community Involvement'. Sociology 37 (1): 103-120.

Mathie, A., Cameron, J. and Gibson, K. 2017. 'Asset-Based and Citizen-Led Development: Using a Diffracted Power Lens to Analyze the Possibilities and Challenges. Progress in Development Studies 17 (1): 54-66.

McClenaghan, P. 2000. 'Social Capital: Exploring the Theoretical Foundations of Community Development Education'. British Educational Research Journal 26 (5): 565582.

Milios, J. 2005. 'European Integration as a Vehicle of Neoliberal Ideology'. In Neoliberalism: A Critical Reader, edited by A. Saad-Filho and D. Johnston, 208-214. London: Pluto Press. 
Ministry of Agriculture and Forestry of Finland. 2019. 'Rural Development Networks'. Accessed 22 February 2019. https://mmm.fi/en/rural-areas/rural-development/ruraldevelopment-networks.

Navarro, F. A., M. Woods and E. Cejudo. 2016. 'The LEADER Initiative Has Been a Victim of Its Own Success: The Decline of the Bottom-Up Approach in Rural Development Programmes - the Cases of Wales and Andalusia'. Sociologia Ruralis 56 (2): 270-288.

Patomäki, H. 2007. Uusliberalismi Suomessa: Lyhyt Historia ja Tulevaisuuden Vaihtoehdot: Helsinki: WSOY.

Pawar, M. 2014. Social and Community Development Practice. New Delhi: Sage.

Ransome, P. 1992. Antonio Gramsci: a New Introduction. Hertfordshire: Harvester Wheatsheaf.

Richardson, A. 1983. Participation. London: Routledge

Rose, N. 1999. Powers of Freedom: Reframing Political Thought. Cambridge: Cambridge University Press.

Rose, N. 2000. 'Community, Citizenship, and the Third Way'. American Behavioral Scientist 43: $1395-1411$.

Rural Policy Committee. 2014. 'Finnish Rural Policy in a Nutshell.' Helsinki: Ministry of Economic Affairs and Employment. 
https://tem.fi/documents/1410877/2937056/Finnish+Rural+Policy+in+a+Nutshell?fbclid=Iw AR1MpagS-j2BxD0dcBZAsG8X_Yt9yvZDl-f36ZiyCAZylWORTmci0MffN2I

Saad-Filho, A. and Johnston, D. eds. 2005. Neoliberalism: A Critical Reader. London: Pluto Press.

Sage, D. 2012. 'A Challenge to Liberalism? The Communitarianism of Big Society and Blue Labour.' Critical Social Policy 32 (3): 365-382.

Schreier, M. 2004. Qualitative Content Analysis in Practice. London: Sage.

Shaw, M. 2004. Community Work: Policy, Politics and Practice. Hull and Edinburgh: Universities of Hull and Edinburgh.

Shucksmith, M. 2012. 'Class, Power and Inequality in Rural Areas: Beyond Social Exclusion'. Sosiologia Ruralis 52 (4): 377-397.

Stenius, H. 2010. 'Nordic Associational Life in a European and Inter-Nordic Perspective'. In Nordic Associations in European Perspective, edited by R. Alapuro and H. Stenius, 29-86. Baden-Baden: Nomos.

Trägårdh, L. 2007. State and Civil Society in Northern Europe: The Swedish Model Reconsidered. New York: Berghahn Books.

Urry, J. 1995. Consuming Places. London: Routledge. 
van Houdt, F., S. Suvarierol and W. Schinkel. 2011. 'Neoliberal Communitarianism Citizenship: Current Trends Towards "Earned Citizenship" in the United Kingdom, France and the Netherlands'. International Sociology 26 (3): 408-432.

Veggeland, N. 2017. 'The Nordic Welfare Model Under the Pressure of EU's Regulatory System.’ Revista Romana de Sociologie 28 (1/2): 99-102.

Walters, W. 2004. 'Some Critical Notes on "Governance”'. Studies in Political Economy 73: $27-46$.

Woods, M. 1997. 'Discourses of Power and Rurality: Local Politics in Somerset in the $20^{\text {th }}$ Century'. Political Geography 16 (6) 453-478.

\section{Data}

The Guidelines of Village Activity', 2000-2002 ('kylätoiminnan suuntaviivat' Suomen kylätoimintayhdisyksen julkaisu, 2000.

'Village Power!', 2003-2007 ('voimaa kuin pienessä kylässä’). Suomen kylätoimintayhdisyksen julkaisu: 2/2003

'The Local Community in Response', 2008-2013 ('vastuuta kantava paikallisyhteisö’). Suomen kylätoimintayhdisyksen julkaisu: 2/2008 http://www.kylatoiminta.fi/uploads/images/tiedostot/yleist $\% \mathrm{C} 3 \% \mathrm{~A} 4 /$ Vastuutaottavapaikallis yhteiso-Kylatoiminnanjaleader-ryhmienvaltakunnallinenohjelma2008-20132-2008.pdf 
'Empowering Villages: Strengthening Local Communities', 2014-2020 ('voimistuvat kylät: vahvistuvat lähiyhteisöt'). Suomen kylätoimintayhdisyksen julkaisu:

http://www.kylatoiminta.fi/uploads/images/tiedostot/oppaat/ohjelma2014_2020_verkkoon.pd $\underline{\mathrm{f}}$ 